\title{
A Conceptual Model for Land System Dynamics as a Coupled Human-Environment System
}

\author{
Richard Aspinall ${ }^{1,2, *}$ (D) and Michele Staiano ${ }^{3}$ \\ 1 Universidad Regional Amazónica IKIAM, Km.7 via Muyuna-Atacapi, Tena CP 150102, Ecuador \\ 2 James Hutton Institute, Craigiebuckler, Aberdeen AB15 8QH, UK \\ 3 Department of Industrial Engineering, University of Naples Federico II, 80, P. le Tecchio, 80125 Napoli, Italy; \\ mstaiano@unina.it \\ * Correspondence: rjaspinall10@gmail.com
}

Received: 4 October 2017; Accepted: 13 November 2017; Published: 16 November 2017

\begin{abstract}
This paper presents a conceptual model of land as a coupled human-environment system. Land use and land cover are incorporated as elements of the human and environment system respectively. Drivers and associated processes that influence land use, land cover, and land system dynamics are incorporated within a set of sub-systems. The model includes consideration of driving sub-systems as a set of capital funds and flows, and how these are influenced by linkages between processes in the human (socio-economic) and environment systems and sub-systems. The model is consistent with existing models of the biophysical earth system used by the land change, earth system sciences, and socio-ecological systems communities. The purposes of the model are to provide (i) a holistic framework within which descriptions, models and analyses that focus on various components of land can be placed to describe and explain land systems and land system changes; and (ii) a guide for the development of more fully integrated and interdisciplinary understanding, analysis and study of land use and land cover dynamics, with explicit focus on relationships between human and natural systems.
\end{abstract}

Keywords: land systems; coupled human-environment system; land change; land system dynamics

\section{Introduction}

Land use, land cover, and the associated dynamics of land systems (including change in cover and use and combining human and environment systems' processes) present fundamental challenges for the sciences that aim to support an understanding of land use and land change [1-3]. Land use traditionally is understood as a variety of human activities (e.g., agriculture, forestry, recreation), many of which actively manage land, primarily for economic, social or environmental outcomes [4]. Land cover describes the biophysical character of the Earth's surface, describing categories of cover that are produced by land use activities through land management $[2,5]$. The close correspondence, but not formal equivalence, between land uses (e.g., forestry) and land cover (e.g., woodlands) has led to the combined and somewhat interchangeable study of use and cover in land systems science, notably in programs such as the International Geosphere-Biosphere Programme/International Human Dimensions Programme Land-Use and Land-Cover Change (LUCC) [2,6] and the NASA program, Land-Cover and Land-Use Change (LCLUCC) [1,7]. Land use and cover are also frequently conflated in classifications [8] and their separation and taxonomy are regularly discussed [9-12].

Lessons learned from programs such as LUCC [2], the NASA LCLUCC [13] and the Global Land Project [14], as well as from large numbers of other studies of land change (see examples in the Journal of Land Use Science, LAND, and other journals), have led to research on land use and land use change adopting a systems-based approach, notably in terms of coupled human-environment 
systems ${ }^{1}$ [3]. Since 2005, the Global Land Project in particular, and the Global Land Programme [15] have promoted the treatment of land use and land cover within a land systems approach. Similarly, a study of Land Use Futures in the UK [16] recommended that land be treated as a system of human and environment systems. However, even within the context of representing land systems as coupled human-environment systems, a general formulation of land systems is poorly defined and developed, even though such a formulation might contribute both to the capacity for comparison across and between case studies and to the generalization of the results of land use and land change studies [17]. A formal systems specification might also guide the development of more fully integrated and interdisciplinary models of land use and land cover dynamics with explicit focus on relationships between human and environment systems.

Given the inherent limitations of characterizing land systems based solely on land use or land cover [9], the complex interrelations and interactions that exist between societies and their uses of land [18], the global scope and scale of land use and land use change [3,19-21], and the central importance of land use to addressing sustainability challenges $[15,19,22,23]$, a broader, inclusive and more detailed conceptual description and definition of land systems as coupled human-environment systems is required.

In this paper, we present a conceptual model for land systems as coupled human-environment systems. The model combines human and environment systems around a series of sub-systems, linkages and interactions between them. The model represents the sub-systems as capital funds, flows from capitals as fluxes, and the influence of dynamics in capital funds as additional drivers of change. The format for presenting the model reflects the structure and design of the model of the coupled atmosphere-ocean system as a Physical Climate System linked to Biogeochemical Cycles $[24,25]$. (However, that model represents all human activity and land use as a single box with a single connection to other elements of the (global) Earth System, a linkage that gives an appearance of lesser significance than recognition of the Anthropocene would imply [15].)

\section{Elements for a Conceptual Model of Coupled Human-Environment Systems for Land Systems Science}

A long record of case studies of land use and land cover change [1,2], meta-analyses of the land change literature [26-28], and synthesis papers [3,15,29] (many associated with the Global Land Project), have identified a number of elements and principal characteristics exhibited by land systems that might usefully be incorporated into a general model of land systems. Additionally, descriptions of land systems identify some characteristic properties. A model should, therefore, include at least these 5 elements:

(i) Consideration of not only environmental and socio-economic driving factors that affect land, but also the various (and multi-scale) social, economic, cultural and environmental activities and processes that have an impact on land and on its use, cover, function and dynamics [30].

(ii) Recognition of both the funds and flows associated with land: stocks and funds include various types of capitals (natural, financial, social, human, physical [31]), as well as the funds of biodiversity [32], and land itself (both use and cover) located in a geographic space. Flows include a variety of goods, services, and other materials as well as ideas, innovation, and values.

(iii) Emphasis on the multi-scale interactions and dynamics of a range of system structures and processes [33-36].

(iv) Recognition and inclusion of the range of benefits derived from land use, cover and management, typically now formalized as ecosystem goods and services [37,38], and problems such as pollution, environmental impacts, biodiversity loss, and other negative consequences of land use, change and management.

1 The terms 'coupled natural and environment system', 'coupled human-natural system', and 'socio-ecological system' are considered equivalent for the purposes of this paper. 
(v) Emphasis on the place-based nature of land use and global change [38,39] and its relevance to the specific architectures of landscapes and communities $[3,40]$ across various geographic and temporal scales [41]. This also includes appreciation and understanding of the complex responses of human and environment systems, drivers and processes to geographical heterogeneity and variability in environmental conditions [38].

Meta-analyses carried out within LUCC provide a list of proximate causes and underlying driving factors, also referred to as direct and indirect drivers of change [26-28,39,42]. These factors are grouped into six sets: (i) demographic; (ii) economic; (iii) technological; (iv) policy and institutional; (v) cultural; and (vi) other, usually environmental [26,27]. These factors were derived from the meta-analysis of existing studies that documented these factors individually and in combination. Since they were published, these factors have become widely used as a de facto standard for structuring description and, to a lesser extent, analysis of change in land systems. The drivers not only force land change in the sense of land cover change and land use change, but also influence other dynamics of land systems. Mechanisms associated with the various processes that drive/force dynamics have been further categorized as (i) enabling (why); (ii) driving (how); and (iii) shaping (where) [43]. Table 1 combines these two structures for characterizing drivers of dynamics in land systems. For the purposes of a general conceptual model, there is merit in separating forcing variables in the system into enabling, driving and shaping factors, and distinguishing them from other characteristics of land systems which are principally emergent properties of the operation of land systems. It should be noted that one of the more singular characteristics of land systems is that the state of the land system can also act as a driving factor, for example through path dependence [44,45].

At the conclusion of the LUCC program, there was discussion of a theory of land science [17]. This discussion identified four aspects and issues that an overarching theory of land change should address:

(1) Behavior of people (agency) and society (structure), and the uses to which land is put, as well as feedbacks between these elements.

(2) Multi-level with respect to people and pixels (the smallest land units), recognizing that they combine in ways that impact their behaviors both singly and collectively $[36,46]$. Hierarchy theory is relevant to this multi-level, multi-scale behavior [47].

(3) Incorporation of the extent to which people and pixels are connected to the broader world in which they exist, both past and present. This is partly the scope of study of teleconnections in land systems [29].

(4) Incorporation of time, both as past time (history) and the future. This is partly encapsulated in path dependence $[44,45]$.

Table 1. Driving Factors for land system dynamics and land change (based on [26-28,39,42,43]).

\begin{tabular}{|c|c|c|c|}
\hline Factors & Enabling (Why) & Driving (How) & Shaping (Where) \\
\hline Demographic & $\begin{array}{l}\text { Natural increment Migration } \\
\text { Population density } \\
\text { Population distribution } \\
\text { Life-cycle features }\end{array}$ & $\begin{array}{l}\text { Infrastructure Extension } \\
\text { Transport } \\
\text { Markets } \\
\text { Settlements } \\
\text { Public Service } \\
\text { Private Company } \\
\text { Social trigger events }\end{array}$ & Demographics \\
\hline Economic & $\begin{array}{l}\text { Market Growth } \\
\text { Commercialization } \\
\text { Economic structures } \\
\text { Urbanization and Industrialization } \\
\text { Special Variables }\end{array}$ & $\begin{array}{l}\text { Agricultural expansion } \\
\text { Permanent cultivation } \\
\text { Shifting cultivation } \\
\text { Cattle ranching } \\
\text { Colonization } \\
\text { Economic shocks }\end{array}$ & Finance, Capital \\
\hline Technological & $\begin{array}{l}\text { Agro-technical change } \\
\text { Applications in the wood sector } \\
\text { Agricultural production factors }\end{array}$ & $\begin{array}{l}\text { Wood extraction } \\
\text { Commercial } \\
\text { Fuel wood } \\
\text { Pole wood } \\
\text { Charcoal production }\end{array}$ & Education \\
\hline
\end{tabular}


Table 1. Cont.

\begin{tabular}{llll}
\hline \multicolumn{1}{c}{ Factors } & \multicolumn{1}{c}{ Enabling (Why) } & \multicolumn{1}{c}{ Driving (How) } & \multicolumn{1}{c}{ Shaping (Where) } \\
\hline Policy and Institutional & $\begin{array}{l}\text { Formal policies } \\
\text { Policy climate } \\
\text { Property rights }\end{array}$ & $\begin{array}{l}\text { Land ownership } \\
\text { Policy shifts }\end{array}$ & Governance, ownership, tenure \\
\hline Cultural & $\begin{array}{l}\text { Public attitudes, values and beliefs } \\
\text { Individual and household behaviors }\end{array}$ & $\begin{array}{l}\text { Leisure } \\
\text { Tourism } \\
\text { Protected areas }\end{array}$ & History, Culture, Tradition \\
\hline Environment & Resources & $\begin{array}{l}\text { Biophysical drivers/trigger events } \\
\text { e.g., floods }\end{array}$ & $\begin{array}{l}\text { Pre-disposing environmental } \\
\text { factors; land characteristics } \\
\text { (soil quality, topography, etc.) }\end{array}$ \\
\hline
\end{tabular}

\section{Systems Model}

The conceptual model for land systems as coupled human-environment systems proposed here attempts to incorporate these various elements within a single diagram. The prominence of box and arrow frameworks in land-change science research is recognized [2]. Similar conceptual models have been developed in other areas, notably, for example, in earth system sciences [24,25]. Similarly, the State-Factor model for soil development [48] has been important in structuring the research and analysis of soils as systems [49].

The purposes of the conceptual model presented here are to provide

(i) A holistic framework within which descriptions, models and analyses that focus on various components of land can be placed to describe and explain land systems and land system changes.

(ii) A guide for the development of more fully integrated and interdisciplinary understanding, analysis and study of land use and land cover dynamics with explicit focus on relationships between human and natural systems.

The conceptual model is shown in Figure 1. The coupled land system has two main component (sub)systems: an environment (biophysical) system and a human (socio-economic) system. Land cover and land use are associated with these two systems respectively. The human system includes demographic, institutional/governance, economic, and technological sub-systems, and the environment system includes the coupled earth system. These sub-systems are considered both as the set of driving factors, operating as process systems in their own right, and as the five capitals (human, social, financial, physical/manufactured, and natural). In addition, there is a subsystem in the human system for decision-making. This makes explicit the additional suite of human and social factors that influence individual and group decisions and decision-making, beyond the inputs and other conditions provided by the five capitals. Agency in the human system is associated with choices and decisions, these being included in the conceptual model by a decision-making subsystem. An additional subsystem labelled "land capability/suitability" for human-environment interaction is also included. This refers to the technical capacities and opportunities for land use that the combined human-environment system offers. These capacities and opportunities are clearly dynamic, reflecting both technical (human system) developments and natural (environment system) capacities.

The main subsystems, as funds, are connected by flows (as fluxes $(\phi)$ and changes $(\delta)$ in the funds). For example, the flows from technical factors to decision making and to economic factors are described as (a) fluxes of products and innovation and (b) changes in technology and other infrastructure (the manufactured capital). The diagram also includes an indication of timescales as days/months/seasons and years/decades. In the case of connections between technical factors with economics and decision-making, the suggested timescale is years to decades.

A major linkage between the human and environment systems is expressed through ecosystem services. These are embedded in the systems approaches of the Millennium Ecosystem Assessment [37] and the Global Land Project [14], and they are key to the current understanding of human-environment relations and natural capital accounting [38,50-52]. Better understanding of ecosystem services as a product of land systems management and as part of the operation of coupled human-environment 
systems will complement the existing emphasis on the roles of biodiversity in supporting ecosystem services $[38,53]$.

Human activities and impacts are listed on the right side of the diagram in Figure 1. Other activities and impacts can be added to these lists. Clearly, the land system as a coupled human-environment system is fully about the roles and impacts of human activities in interaction with environment.

Methods, methodologies and other techniques used for the study of land systems are included, surrounding the central coupled human-environment land system. As with the list of human activities and their impacts, the list provided is not intended to be exclusive. Rather, it is meant to signal the diverse methods necessary to study land systems, emphasizing the human, environment and spatial dimensions evident in much of the existing research literature on land use and land cover [2].

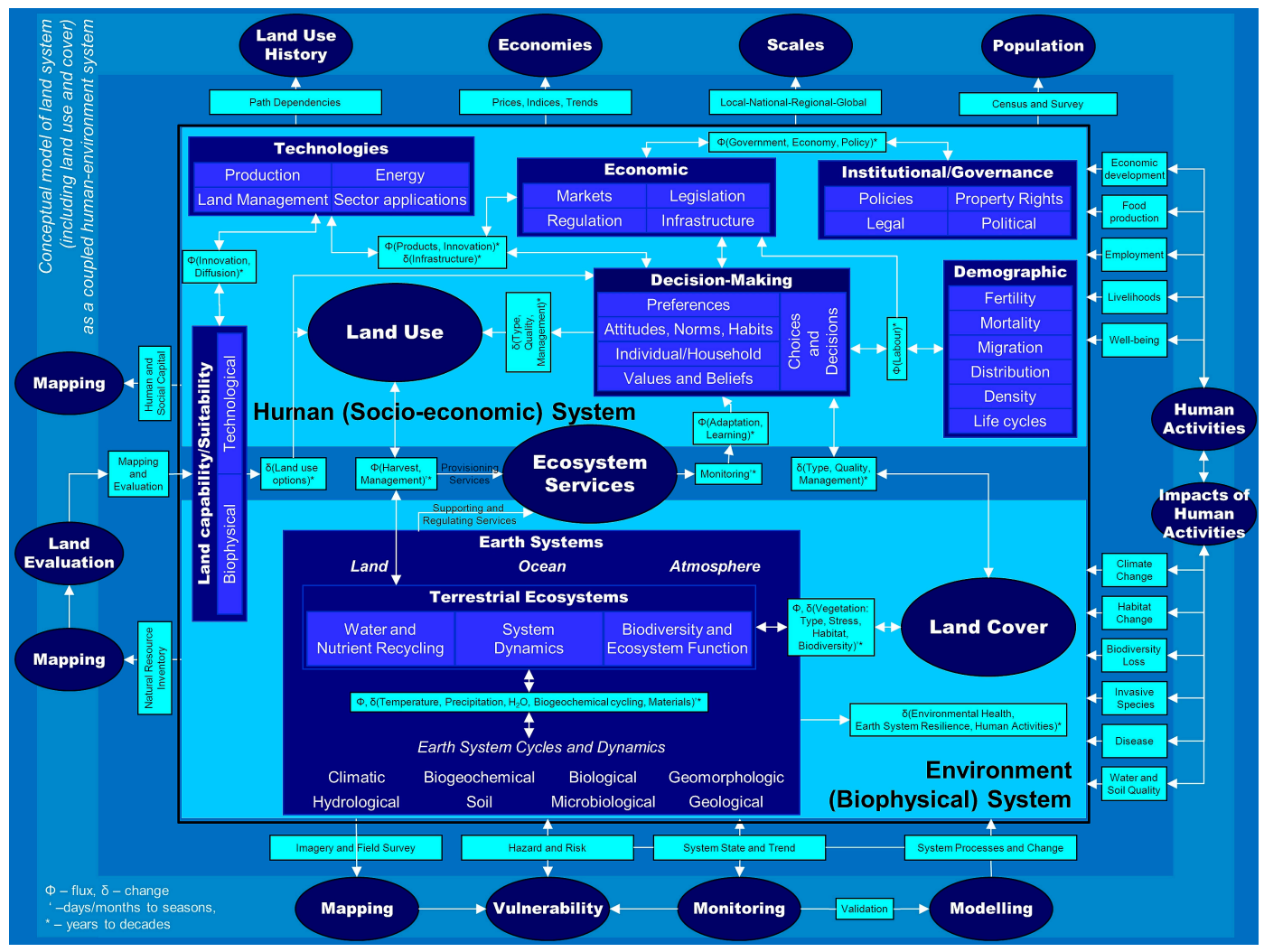

Figure 1. Conceptual model of land system as a coupled human-environment system.

\section{Discussion}

We identified this general model framing land systems-a type of box and arrow framework [17] — to support the study and understanding of land systems, and to inform science, policy, and decision-making [5]. The principal aim of the model is to provide an instrument which contributes to the development of land systems science, and which supports new methods and approaches to the analysis of land systems as manifestations of coupled human-environment systems and processes. This model also aims to allow for comparative studies across various land systems, as well as an improvement to basic and applied understandings of land systems [54,55]. There are four ways in which this conceptual model of land systems as a coupled human-environment system may help.

First, it provides a meta-structure for framing case studies in a broader land systems science, allowing individual case studies to contribute to a wider understanding of the nature of land system dynamics by setting them within a larger and general framework describing the coupled human-environment land systems context. For example, a case study may consider only a subset of 
influences on land cover or land use, while the conceptual model provides a context for following and assessing additional possible influences and feedbacks [56].

Second, it emphasizes the process dynamics of interacting sub-systems within and between the human and environment sub-systems [57]. This provides an opportunity for framing and structuring studies of the sub-systems themselves, as well as connections between the sub-system components, and for scientific analysis of land changes based on addressing processes [58] and causality [59].

Third, it emphasizes an understanding of the multi-scale nature and dynamics of land systems by recognizing the cross-scale and multi-level nature and interactions of drivers, processes and land change [3,60-63]. A wide range of scaling issues are recognized in land systems [46], and differences in space and time scales between human and environment systems are well documented $[64,65]$. The limitations associated with understanding scaling are one of the key attributes of case studies of land use and land cover change that confounds their comparative analysis and the generalization of their results such that they apply beyond the boundaries of the case study area. A fuller appreciation and development of techniques to address the range of scaling issues and to handle multi-scale effects is, therefore, required for the generalization of studies of land change and land system function [35]. The conceptual model invites studies of land systems to be explicit about scaling [33], including multi-scale [36] and multi-level [66] impacts.

Finally, as coupled human-environment systems, land systems demonstrate the full suite of characteristics of complex systems $[57,67,68]$. Similarly, diagnostic analysis of land systems and their dynamics, and the ways in which they change, encounters a set of challenges of description, interpretation, explanation, and understanding of causality, including the challenge of generalization from singular phenomenon. These challenges are common to sciences based on the observation of complex natural and social systems [68,69]. A conceptual model of the full land system can help to structure and frame the study of land as a complex, coupled human-environment system.

\section{Conclusions}

The conceptual model that we describe here aims to visualize a general framework that encapsulates the complex dynamics of land systems at the interface of human and environment systems. The model not only identifies sub-systems that represent various capital funds and the driving processes of sub-systems, but also identifies flows and processes that drive system dynamics. This model also helps to frame ways in which spatial, temporal and organizational scales can be managed. The conceptual model can be used to place and develop individual studies as a part of land systems within a wider framework of whole system analysis and process modelling.

Acknowledgments: Richard Aspinall acknowledges financial support from University of Naples for collaboration with the STAD group based at University of Naples Federico II. We acknowledge the helpful comments of the anonymous referees.

Author Contributions: R.A. conceived the model; R.A. and M.S. wrote the paper.

Conflicts of Interest: The authors declare no conflict of interest.

\section{References}

1. Gutman, G.; Justice, C.O.; Sheffner, E.; Loveland, T. The NASA Land-Cover and Land-Use Change program. In Land Change Science; Gutman, G., Janetos, A.C., Justice, C.O., Moran, E.F., Mustard, J.F., Rindfuss, R.R., Skole, D., Turner, B.L., II, Cochrane, M.A., Eds.; Kluwer Academic Publishers: Dordrech, The Netherlands, 2004; pp. 17-29.

2. Lambin, E.F.; Geist, H. (Eds.) Land-Use and Land-Cover Change: Local Processes and Global Impacts; Springer: Berlin, Germany, 2006; p. 222.

3. Turner, B.L., II; Lambin, E.F.; Reenberg, A. The emergence of land change science for global environmental change and sustainability. Proc. Natl. Acad. Sci. USA 2007, 104, 20666-20671. [CrossRef] [PubMed]

4. Mather, A.S. Land Use; Longman: Harlow, UK, 1986. 
5. Aspinall, R.J.; Hill, M.J. (Eds.) Land Use Change: Science, Policy and Management; CRC Press: Baton Rouge, LA, USA, 2008; p. 185.

6. Lambin, E.F.; Baulies, X.; Bockstael, N.; Fischer, G.; Krug, T.; Leemans, R.; Moran, E.F.; Rindfuss, R.R.; Sato, Y.; Skole, D.; et al. Land-Use and Land-Cover Change (LUCC): Implementation Strategy. In IGBP Report No. 48, IHDP Report No. 10; International Geosphere-Biospehere Programme: Stockholm, Sweden, 1999; p. 125.

7. Justice, C.O.; Gutman, G.; Vadrevu, K.P. NASA Land Cover nad Land Use Change (LCLUC): An interdicisplinary research program. J. Environ. Manag. 2015, 148, 4-9. [CrossRef] [PubMed]

8. Anderson, J.R.; Hardy, E.E.; Roach, J.T.; Witmer, R.E. A Land Use and Land Cover Classification System for Use with Remote Sensor Data; US Department of Interior: Washington, DC, USA, 1976.

9. Comber, A.J. Land use or land cover? J. Land Use Sci. 2008, 3, 199-201. [CrossRef]

10. Comber, A.J.; Wadsworth, R.A.; Fisher, P.F. Using semantics to clarify the conceptual confusion between land cover and land use: The example of 'forest'. J. Land Use Sci. 2008, 3, 185-198. [CrossRef]

11. Jansen, L.J.M. Harmonization of land use class sets to facilitate compatibility and comparability of data across space and time. J. Land Use Sci. 2006, 1, 127-156. [CrossRef]

12. Jansen, L.J.M.; Groom, G.; Carrai, G. Land-cover harmonisation and semantic similarity: Some methodological issues. J. Land Use Sci. 2008, 3, 131-160. [CrossRef]

13. Gutman, G.; Janetos, A.C.; Justice, C.O.; Moran, E.F.; Mustard, J.F.; Rindfuss, R.R.; Skole, D.; Turner, B.L.; Cochrane, M.A. (Eds.) Land Change Science. Observing, Monitoring and Undertanding Trajectories of Change on the Earth's Surface; Kluwer Academic Publishers: Dordrech, The Netherlands; Boston, MA, USA; London, UK, 2004; p. 457.

14. Global Land Project. Science Plan and Implementation Strategy. In IGBP Report No. 53/IHDP Report No. 19; IGBP Secretariat: Stockholm, Sweden, 2005; p. 64.

15. Verburg, P.H.; Crossman, N.; Ellis, E.C.; Heinimann, A.; Hostert, P.; Mertz, O.; Nagendra, H.; Sikor, T.; Erb, K.-H.; Golubiewski, N.; et al. Land system science and sustainable development of the earth system: A global land project perspective. Anthropocene 2015, 12, 29-41. [CrossRef]

16. Foresight Land Use Futures Project. Land Use Futures: Making the Most of Land in the 21st Century. Final Project Report; The Government Office for Science: London, UK, 2010; p. 323.

17. Lambin, E.F.; Geist, H.; Rindfuss, R.R. Introduction: Local processes with global impacts. In Land-Use and Land-Cover Change; Lambin, E.F., Geist, H., Eds.; Springer: Berlin, Germany, 2006; pp. 1-8.

18. Geist, H. (Ed.) Our Earth's Changng Land: An Encyclopedia of Land-Use and Land-Cover Change; Greenwood Press: Westport, CT, USA, 2006; p. 715.

19. Foley, J.A.; DeFries, R.; Asner, G.P.; Barford, C.; Bonan, G.; Carpenter, S.R.; Chapin, F.S.; Coe, M.T.; Daily, G.C.; Gibbs, H.K.; et al. Global consequences of land use. Science 2005, 309, 570-574. [CrossRef] [PubMed]

20. Monfreda, C.; Ramankutty, N.; Foley, J.A. Farming the planet: 2. Geographic distribution of crop areas, yields, physiological types, and net primary production in the year 2000. Glob. Biogeochem. Cycles 2008, 22. [CrossRef]

21. Vitousek, P.M.; Mooney, H.A.; Lubchenco, J.; Melillo, J.M. Human domination of Earth's ecosystems. Science 1997, 277, 494-499. [CrossRef]

22. DeFries, R.S.; Asner, G.P.; Houghton, R.A. (Eds.) Ecosystems and Land Use Change; Geophysical Monograph No. 153; American Geophysical Union: Washington, DC, USA, 2004.

23. DeFries, R.S.; Foley, J.A.; Asner, G.P. Land-use choices: Balancing human needs and ecosystem function. Front. Ecol. Environ. 2004, 2, 249-257. [CrossRef]

24. Earth System Sciences Committee NASA Advisory Council. Earth System Sciences Committee NASA Advisory Council. Earth systems science: Overview. A program for global change. In Report of the Earth System Sciences Committee NASA Advisory Council; NASA: Washington, DC, USA, 1986; p. 49.

25. Earth System Sciences Committee NASA Advisory Council. Earth System Sciences Committee NASA Advisory Council. Earth systems science: A closer view. In Report of the Earth System Sciences Committee NASA Advisory Council; NASA: Washington, DC, USA, 1988; p. 209.

26. Geist, H.J.; Lambin, E.F. Proximate causes and underlying driving forces of tropical deforestation. Bioscience 2002, 52, 143-150. [CrossRef]

27. Geist, H.J.; Lambin, E.F. Dynamic causal patterns of desertification. Bioscience 2004, 54, 817-829. [CrossRef]

28. Keys, E.; McConnell, W.J. Global change and the intensification of agriculture in the tropics. Glob. Environ. Chang. 2005, 15, 320-337. [CrossRef] 
29. Seto, K.C.; Reenberg, A.; Boone, C.G.; Fragkias, M.; Haase, D.; Langanke, T.; Marcotullio, P.; Munro, D.K.; Olah, B.; Simon, D. Urban land teleconnections and sustainability. Proc. Natl. Acad. Sci. USA 2012, 109, 7687-7692. [CrossRef] [PubMed]

30. Verburg, P.H.; van de Steeg, J.; Veldkamp, A.; Willemen, L. From land cover change to land function dynamics: A major challenge to improve land characterization. J. Environ. Manag. 2009, 90, 1327-1335. [CrossRef] [PubMed]

31. Bebbington, A. Capitals and Capabilities: A framework for analyzing peasant viability, rural livelihoods and poverty. World Dev. 1999, 27, 2021-2044. [CrossRef]

32. Diaz, S.; Farglone, J.; Chapin, F.S., III; Tilman, D. Biodiversity loss threatens human well-being. PLoS Biol. 2006, 4, e277.

33. Gibson, C.C.; Ostrom, E.; Ahn, T.K. The concept of scale and the human dimensions of global change: A survey. Ecol. Econ. 2000, 32, 217-239. [CrossRef]

34. Berkes, F.; Hughes, T.P.; Steneck, R.S.; Wilson, J.A.; Bellwood, D.R.; Crona, B.; Folke, C.; Gunderson, L.H.; Leslie, H.M.; Norberg, J.; et al. Globalization, roving bandits, and marine resources. Science 2006, 311, 1557-1558. [CrossRef] [PubMed]

35. Veldkamp, A.; Verburg, P.H.; Kok, K.; de Koning, G.H.J.; Priess, J.; Bergsma, A.R. The Need for Scale Sensitive Approaches in Spatially Explicit Land Use Change Modeling. Environ. Model. Assess. 2001, 6, 111-121. [CrossRef]

36. Verburg, P.H.; Eickhout, B.; van Meijl, H. A multi-scale, multi-model approach for analyzing the future dynamics of European land use. Ann. Reg. Sci. 2008, 42, 57-77. [CrossRef]

37. Millennium Ecosystem Assessment. Ecosystems and Human Well-Being: Synthesis; Island Press: Washington, DC, USA, 2005; p. 137.

38. Potschin, M.B.; Haines-Young, R.H. Ecosystem services: Exploring a geographical perspective. Prog. Phys. Geogr. 2011, 35, 575-594. [CrossRef]

39. Lambin, E.F.; Geist, H.J.; Lepers, E. Dynamics of land-use and land-cover change in tropical regions. Annu. Rev. Environ. Resour. 2003, 28, 205-241. [CrossRef]

40. Turner, B.L., II. Land system architecture for urban sustainability: New directions for land system science illustrated by application to the urban heat island problem. J. Land Use Sci. 2016, 11, 689-697. [CrossRef]

41. Brown, D.G.; Walker, R.; Manson, S.; Seto, K.C. Modeling land-use and land-cover change. In Land Change Science; Gutman, G., Janetos, A.C., Justice, C.O., Moran, E.F., Mustard, J.F., Rindfuss, R.R., Skole, D., Turner, B.L., II, Cochrane, M.A., Eds.; Kluwer Academic Publishers: Dordrecht, The Netherlands, 2004; pp. 395-409.

42. Geist, H.; McConnell, W.J.; Lambin, E.F.; Moran, E.F.; Alves, D.; Rudel, T. Causes and trajectories of land-use/cover change. In Land-Use and Land-Cover Change; Lambin, E.F., Geist, H., Eds.; Springer: Berlin, Germany, 2006; pp. 41-70.

43. Travis, W.R. New Geographies of the American West: Land Use and the Changing Patterns of Place; Island Press: Washington, DC, USA, 2007.

44. Aspinall, R.J. Modelling land use change with generalized linear models-A multi-model analysis of change between 1860 and 2000 in Gallatin Valley, Montana. J. Environ. Manag. 2004, 72, 91-103. [CrossRef] [PubMed]

45. Brown, D.G.; Page, S.; Riolo, R.; Zellner, M.; Rand, W. Path dependence and the validation of agent-based spatial models of land use. Int. J. Geogr. Inf. Sci. 2005, 19, 153-174. [CrossRef]

46. Rounsevell, M.D.A.; Pedroli, B.; Erb, K.H.; Gramberger, M.; Busck, A.G.; Haberl, H.; Kristensen, S.; Kuemmerle, T.; Lavorel, S.; Lindner, M.; et al. Challenges for land system science. Land Use Policy 2012, 29, 899-910. [CrossRef]

47. Allen, T.H.; Starr, T.B. Hierarchy: Perspectives for Ecological Complexity; University of Chicago Press: Chigao, IL, USA, 1982.

48. Jenny, H. Factors of Soil Formation; McGraw Hill: New York, NY, USA, 1941; p. 281.

49. Richter, D.; Yaalon, D.H. “The changing model of soil” revisited. Soil Sci. Socety Am. J. 2011, 76, 766-778. [CrossRef]

50. Liu, S.A.; Costanza, R.; Troy, A.; D’Aagostino, J.; Mates, W. Valuing New Jersey's ecosystem services and natural capital: A spatially explicit benefit transfer approach. Environ. Manag. 2010, 45, 1271-1285. [CrossRef] [PubMed] 
51. Monfreda, C.; Wackernagel, M.; Deumling, D. Establishing national natural capital accounts based on detailed-Ecological footprint and biological capacity assessments. Land Use Policy 2004, 21, 231-246. [CrossRef]

52. Van Keulen, H. Quantitative analyses of natural resource management options at different scales. Agric. Syst. 2007, 94, 768-783. [CrossRef]

53. Daily, G.C.; Polasky, S.; Goldstein, J.; Kareiva, P.M.; Mooney, H.A.; Pejchar, L.; Ricketts, T.H.; Salzman, J.; Shallenberger, R. Ecosystem services in decision making: Time to deliver. Front. Ecol. Environ. 2009, 7, 21-28. [CrossRef]

54. Aspinall, R. Editorial. J. Land Use Sci. 2006, 1, 1-4. [CrossRef]

55. Müller, D.; Munroe, D.K. Current and future challenges in land-use science. J. Land Use Sci. 2014, 9, $133-142$. [CrossRef]

56. Chen, Y.; Bakker, M.M.; Ligtenberg, A.; Bregt, A.K. How are feedbacks represented in land models? Land 2016, 5, 29. [CrossRef]

57. Liu, J.; Dietz, T.; Carpenter, S.R.; Alberti, M.; Folke, C.; Moran, E.F.; Pell, A.N.; Deadman, P.; Kratz, T.; Lubchenko, J.; et al. Complexity of coupled human and natural systems. Science 2007, 317, 1513-1516. [CrossRef] [PubMed]

58. Committee on Needs and Research Requirements for Land Change Modeling. Advancing Land Change Modeling: Opportunities and Research Requirements; National Research Council: Washington, DC, USA, 2013; p. 146.

59. Meyfroidt, P. Approaches and terminology for causal analysis in land systems science. J. Land Use Sci. 2016, 11, 501-522. [CrossRef]

60. Dobson, J.E. Spatial logic in paleogeography and the explanation of continental drift. Ann. Assoc. Am. Geogr. 1992, 82, 187-206. [CrossRef]

61. Parker, D.C.; Entwisle, B.; Rindfuss, R.R.; Vanwey, L.K.; Manson, S.M.; Moran, E.; An, L.; Deadman, P.; Evans, T.P.; Linderman, M.; et al. Case studies, cross-site comparisons, and the challenge of generalization: Comparing agent-based models of land-use change in frontier regions. J. Land Use Sci. 2008, 3, 41-72. [CrossRef] [PubMed]

62. Levin, S.A. The problem of pattern and scale in ecology: The Robert H. MacArthur Award Lecture. Ecology 1992, 73, 1943-1967. [CrossRef]

63. Wu, J. Hierarchy and scaling: Extrapolating information along a scaling ladder. Can. J. Remote Sens. 1999, 25, 367-380. [CrossRef]

64. Agarwal, C.; Green, G.M.; Grove, J.M.; Evans, T.P.; Schweik, C.M. A Aeview and Assessment of Land-Use Change Models: Dynamics of Space, Time and Human Choice; Center for the Study of Institutions, Population and Environmental Change, Indiana University: Indiana, IN, USA, 2002; p. 81.

65. Evans, T.P.; Robinson, D.; Schmitt-Harsh, M. Limitations, challenges, and solutions to integrating carbon dynamics with land-use models. In Land Use and the Carbon Cycle: Advances in Integrated Science, Management, and Policy; Brown, D.G., Robinson, D.T., French, N.H.F., Reed, B.C., Eds.; Cambridge University Press: Cambridge, UK, 2013; pp. 178-208.

66. Tian, Q.; Brown, D.G.; Zheng, L.; Qi, S.; Liu, Y.; Jiang, L. The role of cross-scale and environmental contexts in household-level land-use decisions. Ann. Assoc. Am. Geogr. 2015, 105, 1240-1259. [CrossRef]

67. Carpenter, S.R.; Mooney, H.A.; Agard, R.; Capistrano, D.; DeFries, R.S.; Diaz, S.; Dietz, T.; Duraiappah, A.K.; Oteng-Yeboah, A.; Pereira, H.M.; et al. Science for managing ecosystem services: Beyond the Millennium Ecosystem Assessment. Proc. Natl. Acad. Sci. USA 2009, 106, 1305-1312. [CrossRef] [PubMed]

68. Folke, C.; Carpenter, S.R.; Elmqvist, R.; Gunderson, L.H.; Holling, C.S.; Walker, B. Resilience and sustainable development: Building adaptive capacity in a world of transformations. Ambio 2002, 31, 437-440. [CrossRef] [PubMed]

69. Schumm, S.A. To Interpret the Earth: 10 Ways to Be Wrong; Cambridge University Press: Cambridge, UK, 1998.

(C) 2017 by the authors. Licensee MDPI, Basel, Switzerland. This article is an open access article distributed under the terms and conditions of the Creative Commons Attribution (CC BY) license (http:/ / creativecommons.org/licenses/by/4.0/). 